\title{
EVALUASI STRATEGI PENGELOLAAN WISATA ALAM KAWASAN CURUG LUHUR, KABUPATEN BOGOR
}

\author{
Rikiyama Anugrah Wijaya Fujiyama1), B. Irwan Wipranata ${ }^{2)}$
}

1) Program Studi S1 PWK, Fakultas Teknik, Universitas Tarumanagara, rikiyama.345150018@stu.untar.ac.id

2) Program Studi S1 PWK, Fakultas Teknik, Universitas Tarumanagara, irwan_wipranata@yahoo.co.uk

\begin{abstract}
Abstrak
Wisata alam adalah salah satu jenis wisata yang sangat besar di wilayah Indonesia karena kekayaan dan keindahan suasana alamnya yang tidak terhingga dan jumlah peminat jenis wisata tersebut juga memiliki angka yang tinggi. Salah satu tempat yang memiliki potensi kekayaan wisata alam di sekitar kaki Gunung Salak, Sukabumi adalah berjenis curug atau biasa dikenal sebagai air terjun. Curug Luhur adalah salah satu air terjun yang berpotensi menjadi objek studi pariwisata keberlanjutan. Tetapi sangat disayangkan karena masih terdapat permasalahan pada kawasan tersebut. Salah satu masalahnya adalah strategi pengelolaan yang tidak baik sehingga mengancam kelestarian alam dan keseimbangan ekosistem. Untuk memperbaiki strategi pengelolaan, perlu diketahui beberapa masalah dan potensi pada kawasan tersebut sehingga dapat membuat strategi pengelolaan yang lebih baik dan dapat meningkatkan angka pengunjung tanpa merusak keseimbangan ekosistem di dalamnya dan menjadi pariwisata berkelanjutan. Beberapa aspek yang harus diperhatikan adalah sistem organisasi, aksesibilitas, sarana dan prasarana, sumber daya manusia, daya tarik, dan promosi. Sedangkan dari sudut pandang aspek pariwisata berkelanjutan adalah konservasi, partisipasi masyarakat, ekonomi, dan infrastruktur. Untuk mendapatkan hasil evaluasi strategi pengelolaan, yaitu dengan melakukan penelitian kuantitatif dan kualitatif serta menggunakan metode penelitian berupa wawancara, pengumpulan data, dan survey lapangan dalam melakukan analisis lokasi, kondisi fisik, daya dukung kawasan, best practices, preferensi pengunjung, dan strategi pengelolaan.
\end{abstract}

\section{Kata kunci: air terjun; pariwisata berkelanjutan; pengelolaan}

\begin{abstract}
Nature tourism is one of the very large types of tourism in the territory of Indonesia because of the wealth and beauty of the unlimited natural atmosphere and the high number of enthusiasts of these types of tours. One of the places that have the potential of natural tourism wealth around the foot of Mount Salak, Sukabumi is a curug or commonly known as a waterfall. Curug Luhur is one of the waterfalls that has the potential to be the object of sustainability tourism studies. But it is unfortunate because there are still problems in the area. One problem is the poor management strategy that threatens the preservation of nature and the balance of the ecosystem. To improve management strategies, it is necessary to know a number of problems and potentials in the region so that they can create better management strategies and increase visitor numbers without destroying the ecosystem balance and becoming sustainable tourism. Some aspects that must be considered are the organizational system, accessibility, facilities and infrastructure, human resources, attractiveness, and promotion. While from the perspective of the aspects of sustainable tourism are conservation, community participation, economy, and infrastructure. To get the results of evaluating the management strategy, namely by conducting quantitative and qualitative research and using research methods in the form of interviews, data collection, and field surveys in analyzing locations, physical conditions, carrying capacity of the area, best practices, visitor preferences, and management strategies.
\end{abstract}

Keywords: management; sustainable tourism; waterfall 


\section{PENDAHULUAN}

Kabupaten Bogor adalah suatu wilayah yang terkenal dengan kekayaan wisata alam yang sangat indah. Wisata di wilayah ini juga menjadi salah satu pilihan utama bagi masyarakat Jakarta yang ingin mencari hiburan wisata alam dan sudah penat dengan kondisi perkotaan. Banyak pilihan atau jenis yang tersedia jika ingin menikmati wisata alam di Kabupaten Bogor dari pegunungan, air terjun, taman konservasi, kebun binatang, danau, dll. Ada juga tempat untuk para pecinta hobi tertentu, seperti paralayang, sirkuit balap, arum jeram, dll.

Wisata alam adalah salah satu jenis wisata yang sangat besar di wilayah Indonesia karena kekayaan dan keindahan suasana alamnya yang tidak terhingga dan jumlah peminat jenis wisata tersebut juga memiliki angka yang tinggi. Fasilitas adalah salah satu hal utama yang dibutuhkan dalam kawasan wisata alam. Banyaknya peminat atau pengunjung juga bisa mengancam tempat wisata alam tersebut jika tidak memiliki fasilitas yang baik dan lengkap. Hal ini Para pengelola juga harus menjaga dan tanggung jawab terhadap kondisi kelestarian dari alam yang akan dijadikan tempat wisata alam tersebut. Salah satu tempat yang memiliki potensi kekayaan wisata alam di sekitar kaki Gunung Salak, Sukabumi adalah berjenis air terjun atau biasa dikenal sebagai curug. Terdapat 5 air terjun disekitar kawasan tersebut yang bernama Curug Putri, Curug Cihurang, Curug Cadas Ngampar, Curug Ngumpet, dan Curug Luhur. Dan penulis memilih Curug Luhur sebagai objek studi.

Curug Luhur adalah salah satu air terjun yang terletak di Desa Tapos I, Kecamatan Tenjolaya, Kabupaten Bogor. Nama Curug Luhur memiliki makna tersendiri yaitu curug tinggi atau tertinggi Hal itu disebabkan air terjun ini adalah air terjun tertinggi yang ada di kawasan kaki gunung Salak dengan ketinggian 62 meter dari permukaan tanah. Total luas lahan air terjun ini sebesar 2,7 hektar. Akses untuk ke lokasi juga cukup mudah karena lokasi wisata berdekatan dengan jalan raya. Tempat wisata ini tidak hanya menyajikan indahnya air terjun saja, Curug Luhur juga terdapat kolam renang buatan dengan air yang berasal dari air terjun tersebut. Kombinasi antara wisata alam dan wisata buatan adalah salah satu hal yang membedakan air terjun ini dengan air terjun lain disekitarnya. Sehingga tiket masuk air terjun ini menjadi termahal di kawasan tersebut dengan harga Rp. 40,000 / orang.

\section{KAJIAN LITERATUR Ekosistem}

Menurut UU Lingkungan Hidup tahun 1997, mengatakan bahwa ekosistem adalah tatanan satu kesatuan cara yang begitu utuh serta menyeluruh antara segenap unsur lingkungan hidup untuk saling mempengaruhi. Unsur-unsur lingkungan hidup ini dapat disebut unsur biotik dan abiotik, baik makhluk hidup maupun benda mati di dalamnya. Ekosistem bisa dikatakan sebagai suatu kesatuan antara alam dengan makhluk hidup organisme yang ada disekitar lingkungan alam dengan cara hubungan timbal balik yang dapat mempengaruhi sistem ekologi lingkungan alam tersebut.

\section{Pariwisata Berkelanjutan (Sustainable Tourism)}

Menurut Muller (1992), Pariwisata Berkelanjutan (Sustainable Tourism) adalah suatu konsep pariwisata yang dikelola dengan acuan pada pertumbuhan kualitatif dengan maksud dalam meningkatkan kesejahteraan, perekonomian dan kesehatan masyarakat. Berikut adalah beberapa kriteria yang harus dipenuhi oleh kawasan wisata yang dianggap berkelanjutan.

a. Mampu berkelanjutan secara lingkungan yaitu pembangunan pariwisata tidak menimbulkan efek negatif bagi ekosistem setempat. Selain itu, konservasi merupakan kebutuhan yang harus diupayakan untuk melindungi sumberdaya alam dan lingkungan dari efek negatif kegiatan wisata (environmentally sustainable).

b. Secara sosial dan kultural dapat diterima yaitu mengacu kepada kemampuan masyarakat lokal untuk menyerap aktivitas pariwisata tanpa menimbulkan konflik sosial, serta masyarakat lokal mampu beradaptasi dengan budaya wisatawan yang cukup berbeda 
(socially and culturally acceptable).

c. Secara ekonomis menguntungkan dan layak, artinya keuntungan yang diperoleh dari kegiatan pariwisata dapat meningkatkan kesejahteraan masyarakat (economically viable).

d. Memanfaatkan teknologi yang layak/pantas untuk diterapkan di wilayah lingkungan tersebut (technologically appropriate).

\section{Pengelolaan Wisata Alam}

Menurut Peraturan Menteri Kehutanan No. 4 Tahun 2012, Pengelolaan pariwisata alam di Taman Nasional dapat dilakukan di zona pemanfataan. Kegiatan pengelolaan dan pengembangan pariwisata alam dapat dilakukan di taman nasional dengan memperhatikan asas kelestarian. Berikut adalah beberapa hal dan keperluan standar yang harus dilakukan dalam kegiatan pengelolaan pariwisata alam.

a. Transportasi dan Jasa Angkutan, jasa yang bergerak di bidang angkutan darat, laut, dan udara.

b. Akomidasi, suatu tempat untuk para wisatawan sebagai tempat tinggal sementara.

c. Daya Tarik Wisata, sesuatu yang dijadikan sebagai icon yang memiliki keunikan dan nilai yang menjadi tujuan kunjungan wisatawan berupa keanekaragaman dan kekayaan alam.

d. Souvenir, suatu benda untuk wisatawan sebagai kenangan dari tempat wisata yang bisa dibawa kembali ke tempat asal para wisatawan.

e. Lansekap Alami, bentangan alam yang dapat dinikmati oleh wisatawan dari perspektif tempat wisata dengan karakteristik yang alami dan harmonis.

f. Kawasan Hutan, beberapa wilayah yang ditentukan oleh pemerintah untuk dipertahankan kondisinya sebagai hutan tetap dan juga bisa dijadikan sebagai batas pengembangan wilayah wisata alam.

g. Pengelolaan Distribusi Pengunjung, pengaturan kuota dan distribusi jumlah pengunjung dalam suatu kawasan wisata sebagai upaya untuk menghindari kerusakan obyek wisata, keamanan pengunjung, dan gangguan terhadap flora dan fauna yang berada di lokasi wisata.

\section{METODE}

Data yang dikumpulkan pada proses penelitian adalah data lokasi dan fasilitas Curug Luhur, Masterplan Curug Luhur, data jumlah pengunjung, data pengelolaan kawasan Curug Luhur, Benchmarking, dan data kebijakan kawasan berdasarkan Peta Rencana Pola Ruang Kabupaten Bogor. Teknik pengumpulan data yang digunakan dalam proses penelitian terbagi menjadi dua metode, yaitu pengumpulan data primer dan pengumpulan data sekunder. Dalam metode pengumpulan data primer dilakukan dengan survey lapangan, wawancara, dan penyebaran kuisioner. Sedangkan untuk metode pengumpulan data sekunder dilakukan dengan dokumentasi dan sumber yang relevan seperti studi literatur, internet, buku, dan skripsi.

Analisis yang digunakan dalam penelitian ini adalah analsisi lokasi, analisis kondisi fisik, analisis preferensi pengunjung, analisis daya dukung kawasan, analisis best practice, dan analisis strategi pengelolaan. Alat analisis yang digunakan untuk menyelesaikan analisis tersebut adalah deskriptif, SWOT, Crosstab, diagram cartesius, skate likert, dan physical carrying capacity.

\section{DISKUSI DAN HASIL}

Analisis Lokasi

Aksesibilitas

Tabel 1. Akses menuju Curug Luhur

\begin{tabular}{|c|c|c|c|}
\hline No & Lokasi Asal & Akses & Keterangan \\
\hline \multirow{4}{*}{1.} & & Tol Jagorawi - Jalan Raya Pajajaran - Jalan & \\
\hline & & Otto Iskandardinata - Jalan IR. H. Juanda & Jarak Tempuh 60 km \\
\hline & alternatif 1 & - Jalan Empang - Jalan Raya Ciapus - Jalan & Waktu Tempuh 1 jam 42 menit \\
\hline & & $\begin{array}{l}\text { Gn. Malang - Jalan Curug Luhur - Jalan } \\
\text { Cikaret - Jalan Hegarmanah }\end{array}$ & \\
\hline
\end{tabular}




\begin{tabular}{|c|c|c|c|}
\hline 2. & $\begin{array}{l}\text { Jakarta } \\
\text { alternatif } 2\end{array}$ & $\begin{array}{l}\text { Tol Jagorawi - Tol Lingkar Luar Bogor - } \\
\text { Jalan KH. R. Abdullah Bin Nuh - Jalan Raya } \\
\text { Cifor - Jalan Raya Dramaga - Jalan Raya } \\
\text { Leuwiliang - Jalan Raya Cinangneng - } \\
\text { Jalan Pasir Reungit - Jalan Hegarmanah }\end{array}$ & $\begin{array}{l}\text { Jarak Tempuh } 67 \mathrm{~km} \\
\text { Waktu Tempuh } 1 \text { jam } 36 \text { menit }\end{array}$ \\
\hline 3. & Sukabumi & $\begin{array}{l}\text { Jalan Ruas Bogor-Sukabumi - Jalan } \\
\text { Tangkil - Jalan Raya Pajajaran - Jalan Otto } \\
\text { Iskandardinata - Jalan IR. H. Juanda - } \\
\text { Jalan Empang - Jalan Raya Ciapus - Jalan } \\
\text { Gn. Malang - Jalan Curug Luhur - Jalan } \\
\text { Cikaret - Jalan Hegarmanah }\end{array}$ & $\begin{array}{l}\text { Jarak Tempuh } 55 \mathrm{~km} \\
\text { Waktu Tempuh } 1 \text { jam } 46 \text { menit }\end{array}$ \\
\hline 4. & $\begin{array}{c}\text { Rangkasbitu } \\
\text { ng }\end{array}$ & $\begin{array}{l}\text { Jalan Jendral Sudirman - Jl, Nasional } 11 \text { - } \\
\text { Jalan Raya Cigudeg - Jalan Raya Kalong II } \\
\text { Jalan Raya Sadeng - Jalan Raya Jambu - } \\
\text { Jalan Raya Leuwiliang - Jalan Kapten } \\
\text { Dasuki Bakri - Jalan Pasir Reungit - Jalan } \\
\text { Hegarmanah }\end{array}$ & $\begin{array}{l}\text { Jarak Tempuh } 83 \mathrm{~km} \\
\text { Waktu Tempuh } 2 \text { jam } 37 \text { menit }\end{array}$ \\
\hline 5. & Cianjur & $\begin{array}{l}\text { Jalan Nasional III - Jalan Ir. H. Djuanda - } \\
\text { Jalan Raya Ciawi - Jalan Raya Puncak - } \\
\text { Jalan Labuan - Jalan Otto Iskandardinata } \\
\text { - Jalan IR. H. Juanda - Jalan Empang - } \\
\text { Jalan Raya Ciapus - Jalan Gn. Malang - } \\
\text { Jalan Curug Luhur - Jalan Cikaret - Jalan } \\
\text { Hegarmanah }\end{array}$ & $\begin{array}{l}\text { Jarak Tempuh } 77 \mathrm{~km} \\
\text { Waktu Tempuh } 2 \text { jam } 44 \text { menit }\end{array}$ \\
\hline
\end{tabular}

Berdasarkan tabel tersebut, maka akses untuk mencapai lokasi objek studi dapat melalui berbagai arah dan hal ini dapat menunjukkan suatu potensi bahwa adanya beberapa pengunjung dari berbagai daerah yang cukup besar. Berikut adalah peta akses untuk menuju lokasi objek studi.

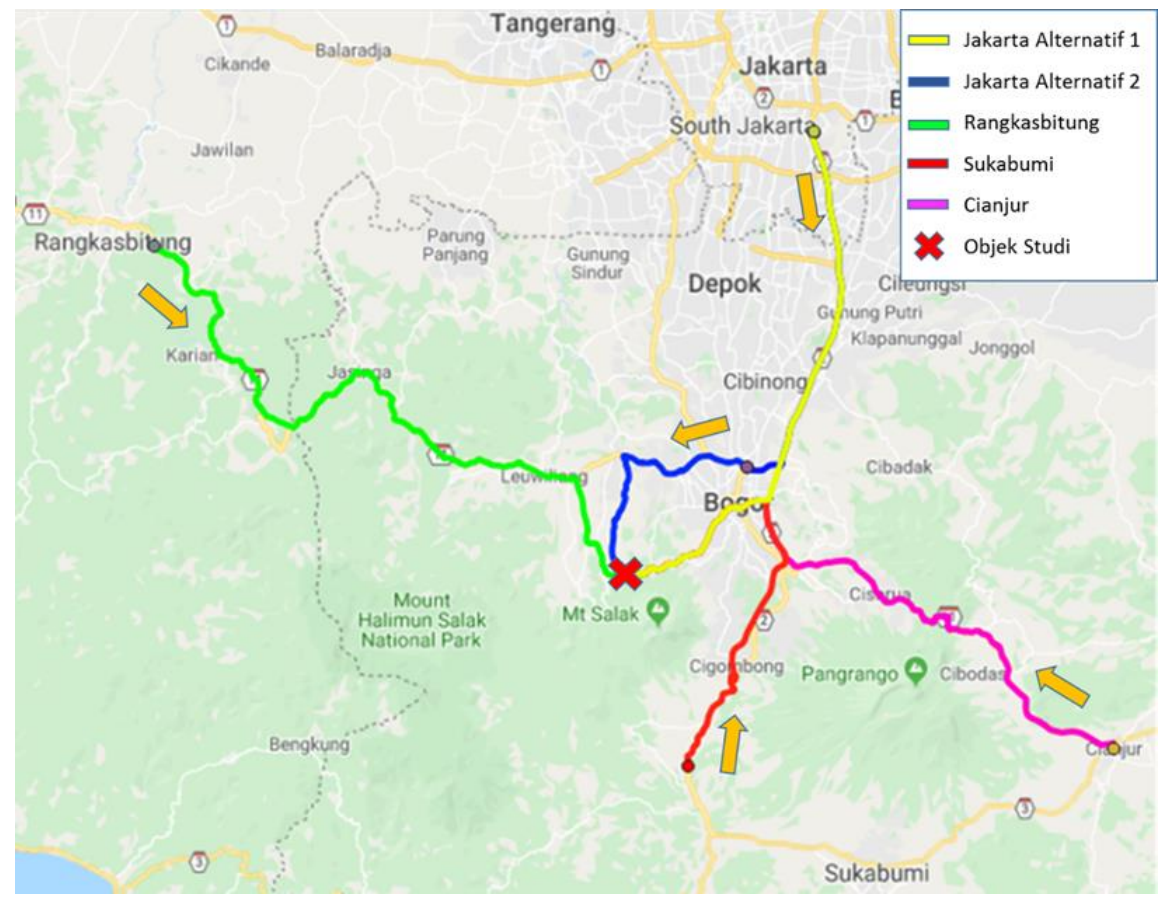

Gambar 1. Aksesibilitas

Sumber: Olahan Penulis, 2019 


\section{Kebijakan}

Berdasarkan kebijakan pemerintah, bisa diketahui bahwa dalam Rencana Tata Ruang Wilayah (RTRW) Kabupaten Bogor bagian rencana pola ruang, kawasan air terjun Curug Luhur merupakan kawasan hutan lindung konservasi. Jika dilihat dengan keadaan eksisting, kawasan objek studi sudah sesuai dengan peraturan kebijakan pemerintah.

\section{Analisis Kondisi Fisik}

\section{Sarana}

\section{a) Saung}

Saung yang berada di kawasan air terjun Curug Luhur berguna untuk tempat bersantai, titik kumpul, dan tempat untuk melakukan kegiatan - kegiatan tertentu bagi para pengunjung. Bahan yang digunakan untuk saung ini terbuat dari kayu dan bamboo dengan kondisi dan kualitaas yang masih cukup baik dan layak pakai. Lokasi saung yang tersebar di kawasan objek studi juga berbeda - beda. Beberapa lokasi saung tersebut adalah dekat air terjun, dekat kolam renang, dan di bukit dekat dengan taman bermain. Saung ini juga tidak dipungut biaya sehingga para pengunjung bebas memilih lokasi yang diinginkan. Tetapi, walaupun tidak dipungut biaya dan kualitas saung masih cukup baik, beberapa saung masih dalam kondisi kotor dan berdebu dikarenakan sepi pengunjung sehingga pengelola hanya membersihkan saung tersebut jika sudah mendekati weekend saja.
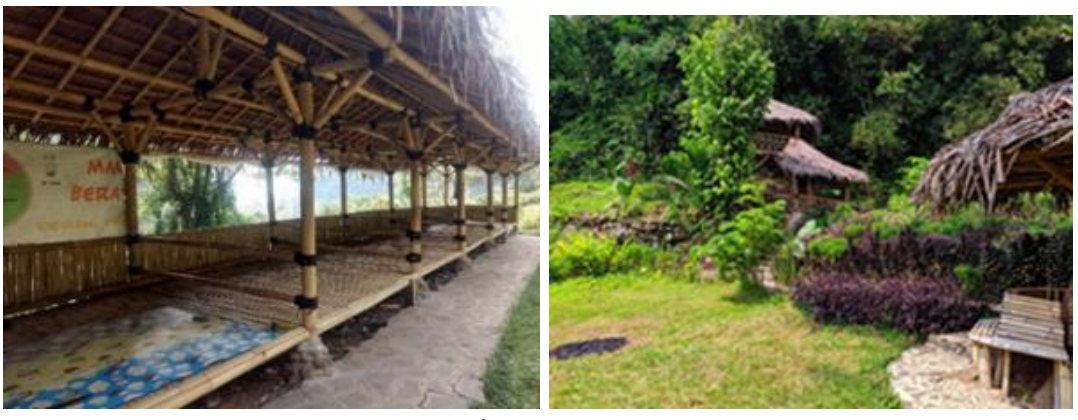

Gambar 2. Saung

Sumber : Penulis, 2019

b) Kolam Renang

Terdapat beberapa kolam renang di air terjun Curug Luhur dengan kedalaman dan seluncuran yang beragam. Pembangunan waterpark di tempat objek studi dimulai pada tahun 2005. Waterpark ini juga memiliki konsep pembangunan yang cukup unik, yaitu mengisi kolam renang memakai air sungai terdekat, yaitu sungai Cinangleng dengan konsep terasering sehingga air akan tetap mengalir dari kolam renang yang berlokasi lebih tingi ke kolam renang yang lebih rendah dan air akan mengalir kembali ke sungai tersebut. Untuk mengalirkan air dari satu kolam ke kolam lainnya, pengelola hanya membuat paralon yang ditanam di sekitar pinggiran kolam dengan ketinggian tertentu pada setiap kolam yang ada di kawasan objek studi.

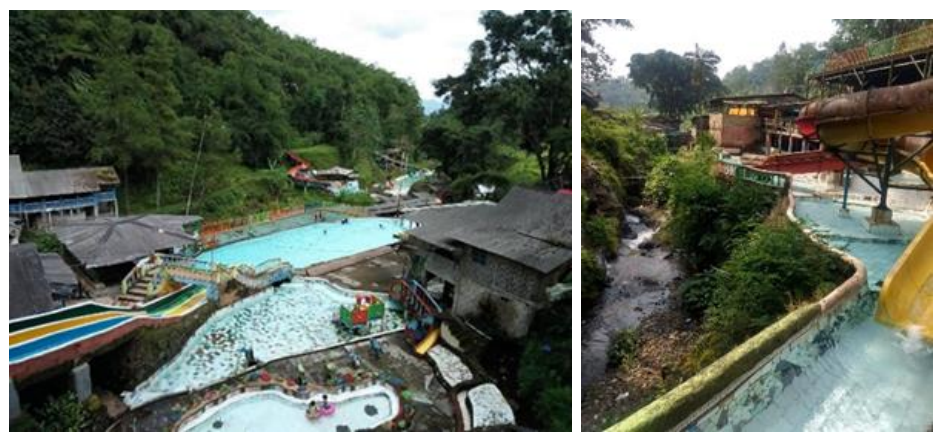

Gambar 3. Kolam Renang

Sumber : Penulis, 2019 


\section{c) Warung Makan}

Seluruh warung makan yang tersebar di kawasan objek studi dikelola oleh penjual dari masyarakat sekitar yang bekerjasama dengan pengelola. Bahan yang digunakan untuk bangunan warung tersebut memakai kayu dan bambu. Produk yang dijual di warung makan tersebut terdapat beberapa variasi seperti, mie ayam, baso, gorengan, makanan ringan, dan minuman. Saat hari biasa, kondisi warung cenderung sepi pengunjung dan kursi warung tersebut dirapihkan dengan menaruh kursi diatas meja. Para penjual tidak membayar uang sewa kepada pengelola tetapi tetap membayar untuk biaya kebersihan dan keamanan. Harga tersebut juga beragam, jika hari biasa berjumlah Rp 50.000,- setiap minggu, tetapi di hari raya dikenakan harga Rp 200.000,- setiap minggu nya.kepada pihak pengelola. Biaya ini digunakan untuk melakukan perbaikan terhadap kerusakan warung.

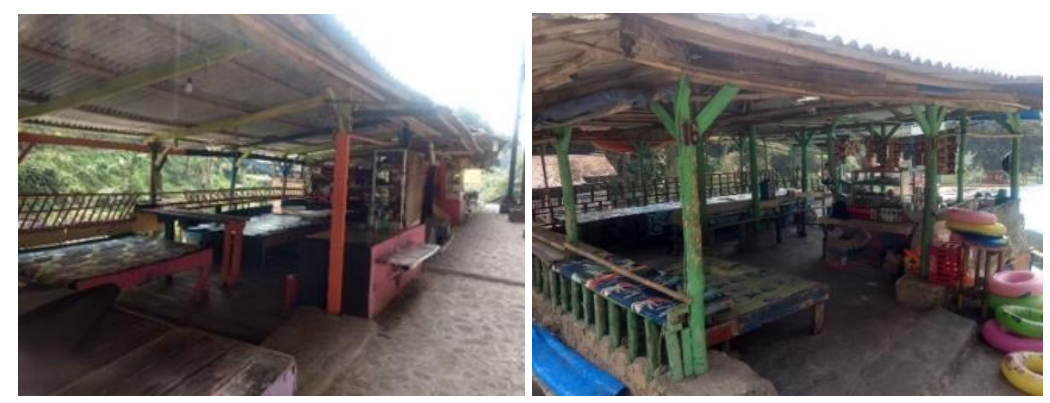

Gambar 4. Warung Makan

Sumber : Penulis, 2019

\section{d) Taman Bermain}

Taman bermain yang ada pada objek studi berjumlah 2 dengan lokasi yang berbeda. Lokasi taman bermain tersebut berada di sebelah timur objek studi berdekatan dengan saung yang berlokasi di bukit dan sisanya berlokasi di dekat warung makan. Bahan yang dipakai untuk membuat taman bermain ini menggunakan besi dan kondisi besi dan cat taman bermain tersebut masih cukup baik. Untuk menikmati taman bermain ini tidak dikenakan biaya dan perawatan yang dilakukan oleh pengelola adalah mengecat ulang taman bermain setiap 3 bulan.
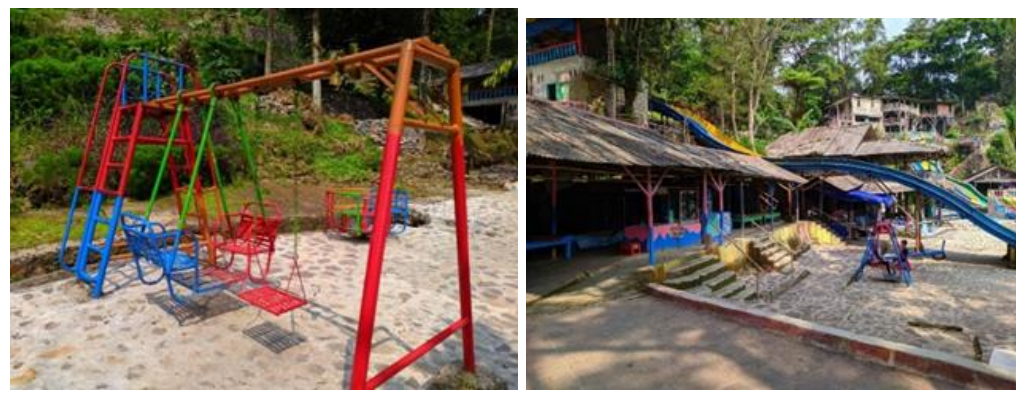

Gambar 5. Taman Bermain

Sumber : Penulis, 2019

\section{e) Peribadatan}

Sarana peribadatan yang tersedia di kawasan objek studi adalah musholla. Lokasi musholla tersebut berada di sisi kiri dekat pintu masuk menuju kawasan air terjun Curug Luhur. Musholla tersebut dapat diapakai untuk pria maupun wanita dengan daya tamping sekitar 10 orang dan sudah dilengkapi dengan tempat berwudhu yang menggunakan mata air. Bahan yang digunakan musholla tersebut menggunakan rangka kayu dan bambu. Pengelola kawasan objek studi adalah pihak yang bertanggung jawab untuk menjaga dan merawat musholla tersebut dan kondisi musholla tersebut masih terlihat bersih dan terawat. 


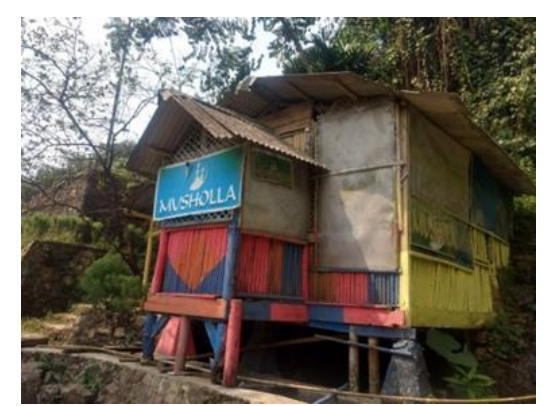

Gambar 6. Peribadatan

Sumber : Penulis, 2019

f) Toilet

Terdapat beberapa toilet yang tersebar di kawasan objek studi dengan kondisi yang berbeda - beda. Tetapi secara keseluruhan, kondisi toilet umum masih terkesan kumuh dan tidak terawat. Masih terdapat beberapa debu dan lumut yang menempel di dinding dan lantai. Beberapa toilet ada yang tidak terdapat kunci pintu dan kondisi lantai keramiknya juga masih ada yang pecah dan belum diperbaiki. Bahkan beberapa toilet mendapatkan penerangan yang cukup sedikit dikarenakan tidak ada ventilasi dan lampu yang redup. Untuk memakai toilet, dikenakan biaya sebesar Rp. 2.000,- untuk buang air dan sebesar Rp. 5.000,- untuk bilas dan mandi. Sumber air yang digunakan untuk toilet umum di area objek studi berasal dari air sumur yang ditampung di toren.

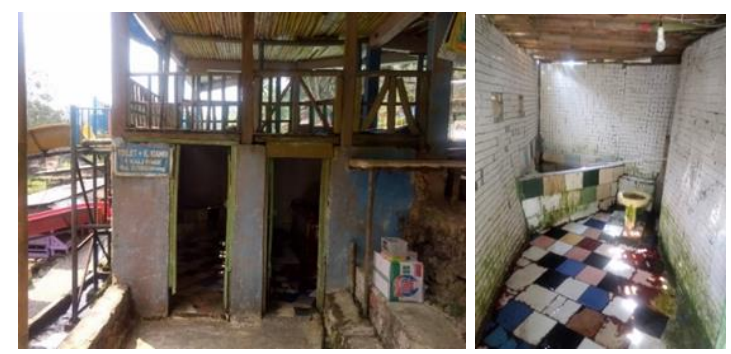

Gambar 7. Toilet

Sumber : Penulis, 2019

g) Parkir

Disekitar kawasan objek studi juga disediakan sarana parkir untuk memarkirkan kendaraan pribadi beroda empat dan roda dua. Harga yang ditentukan oleh pengelola untuk parkir adalah sekitar Rp 10.000,- untuk rmotor dan Rp 15.000,- untuk mobil. Kapasitas kendaraan yang dapat ditampung oleh lahan parkir ini sekitar 30 mobil dan 70 motor. Kapasitas parkir yang tinggi tentu membutuhkan sumber daya manusia yang mencukupi sehingga kendaraan di tempat parkir menjadi teratur. Tetapi tempat parkir ini hanya memiliki satu petugas yang mengatur seluruh parkiran di kawasan objek studi. Sehingga dalam segi pengelolaan sistem parkir kendaraan di kawasan objek studi masih kurang baik yang mengakibatkan beberapa kendaraan menjadi terparkir secara tidak teratur.
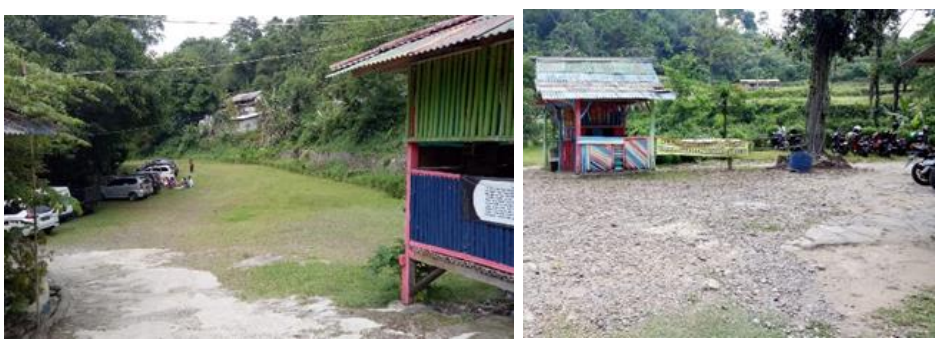

Gambar 8. Parkiran Mobil dan Motor Sumber : Penulis, 2019 


\section{Prasarana}

a) Kebersihan

Kondisi kebersihan lingkungan eksisting dari objek studi masih bisa dikatakan memprihatinkan walaupun beberapa usaha yang dilakukan oleh masyarakat pemilik warung sudah cukup baik untuk menjaga kebersihan warung dan sekitarnya. Hal ini disebabkan masih ada beberapa sampah yg masih berserakan disekitar tempat sampah sedangkan tempat sampah tersebut masih kosong. Untuk pemungutan sampah yang sudah terkumpul dilakukan oleh petugas sampah setempat. Bisa disimpulkan bahwa kesadaran masyarakat dan pengelola masih minim untuk menjaga kebersihan lingkungan objek studi dan hal ini dapat mengganggu ekosistem lingkungan objek studi.

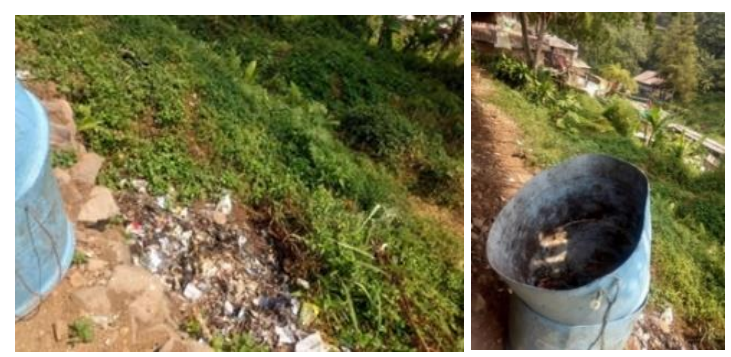

Gambar 9. Tempat Sampah

Sumber : Penulis, 2019

b) Air Bersih

Sistem air bersih yang dipakai oleh pengelola untuk kawasan air terjun Curug Luhur adalah air yang bersumber dari sumur yang ditampung. Kondisi dari kualitas air sudah cukup bagus. Tetapi, kapasitas air bersih yang tersedia belum terpenuhi secara merata untuk setiap toilet sehingga pengunjung tidak bisa memakai beberapa toilet yang tidak mendapat air bersih.

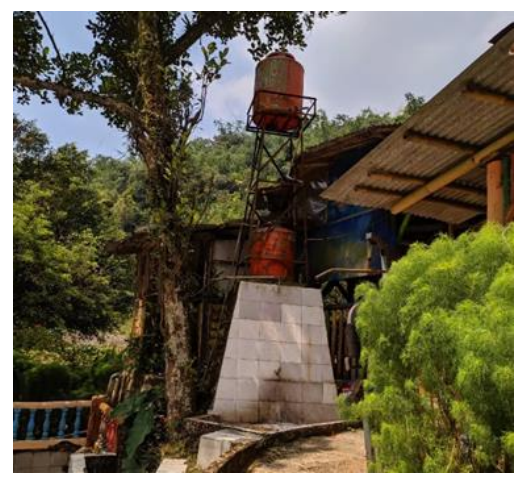

Gambar 10. Penampung Air Bersih

Sumber : Penulis, 2019

c) Kelistrikan

Kondisi dari pemasokan kelistrikan di kawasan objek studi sudah cukup terlayani, walapun masih ada beberapa sarana yang tidak mendapat pasokan listrik, yaitu sarana toilet dan saung. Masalah kelistrikan dari kedua sarana ini adalah kurangnya penerangan karena tidak ada lampu dan hanya mengandalkan cahaya matahari, sehingga beberapa toilet dan saung tidak mendapatkan cahaya yang dibutuhkan. Meskipun aktivitas di malam hari tidak terlalu banyak karena batas kunjungan hanya sampai jam enam sore, kawasan objek studi juga masih kekurangan penerangan saat malam hari, sehingga hanya mengandalkan lampu dari warung makan dan beberapa saung yang sudah dilengkapi dengan lampu. Biaya yang dikeluarkan oleh pihak pengelola kawasan objek studi untuk kelistrikan yaitu sekitar Rp. 500.000,-/bulan. 


\section{Vegetasi}

Analisis vegetasi berguna untuk mengetahui kondisi lingkungan yang berkaitan dengan flora atau tumbuhan di sekitar kawasan objek studi. Berikut adalah beberapa jenis tumbuhan yang tersebar di kawasan Curug Luhur.

Tabel 2. Jenis Tanaman di Kawasan Curug Luhur

\begin{tabular}{cll}
\hline No. & \multicolumn{1}{c}{ Jenis Tanaman } & \multicolumn{1}{c}{ Suku (Famili) } \\
\hline 1. & Bunga Kemboja Merah (Plumeria Obtusa) & Apocynaceae \\
\hline 2. & Bunga Melati (Orchidaceae) & Oleaceae \\
\hline 3. & Bunga Mawar Merah (Rosa spp.) & Rosaceae \\
\hline 4. & Bunga Kembang Kertas (Bougainvillea Spectabilis) & Nyctaginaceae \\
\hline 5. & Bunga Angrek Jamrud (Dendrobium Macrophyllum) & Orchidaceae \\
\hline 6. & Bambu Tamiang (Schyzostachyum sp.) & Poaceae \\
\hline 7. & Pohon Damar (Agathis Dammara) & Araucariaceae \\
\hline 8. & Pohon Pinus (Pinus Merkusii) & Pinaceae \\
\hline 9. & Pohon Berangan (Castanopsis Javanica) & Fagaceae \\
\hline 10. & Pohon Jenitri (Elaecocarpus Ganitrus) & Elaeocarpaceae \\
\hline
\end{tabular}

Sumber : Pengelola Curuh Luhur dan Olahan Penulis

\section{Analisis Daya Dukung Kawasan}

\section{Daya Dukung Fisik}

Berikut adalah rumus perhitungan untuk daya dukung fisik (Physical Carrying Capacity).

Keterangan :

$$
\mathrm{PCC}=A \times \frac{1}{B} \times R f
$$

PCC = Daya dukung fisik (Physical Carrying Capacity)

$\mathrm{A} \quad=$ Luas daerah yang digunakan untuk berwisata

$\mathrm{B}$ = Luas daerah yang dibutuhkan untuk setiap wisatawan dengan tetap mendapatkan kepuasan dalam berwisata (nilai tetap yang digunakan oleh penulis untuk perhitungan ini adalah nilai tetap area piknik oleh Douglas (1975) dalam Fandeli (2009: 72) sebesar $65 \mathrm{~m}^{2}=0,0065 \mathrm{Ha}$ ).

$\mathrm{Rf}$ = Lama buka area wisata dalam waktu satu hari dibagi dengan rata - rata lama waktu wisata.

Berikut adalah hasil yang diperoleh dari perhitungan berdasarkan rumus di atas.

$$
\begin{aligned}
& \mathrm{PCC}=A \times \frac{1}{B} \times R f \\
& \quad \mathrm{PCC}=2,1 \mathrm{Ha} \times \frac{1}{0,0065 \mathrm{Ha}} \times \frac{12 \mathrm{jam}}{4 \mathrm{jam}} \\
& \mathrm{PCC}=2,1 \mathrm{Ha} \times 153,84 \times 3 \\
& \mathrm{PCC}=969,19 \mathrm{Ha}
\end{aligned}
$$

Kapasitas Tampung :

$$
K T=\frac{8.395 j i w a}{969,19 \mathrm{Ha}}=9 \text { orang }
$$

\section{Daya Dukung Ekologi}

Dalam perhitungan daya dukung ekologi, penulis menggunakan rumus Douglas (RW, 1975). Berikut adalah rumus tersebut.

Keterangan :

$$
\mathrm{KA}=\frac{D \times L}{C D \times T F \times 43,560 f t^{2}}
$$

$\mathrm{KA}=$ Kebutuhan areal $\left(\mathrm{m}^{2}\right)$

$C D=$ Total jumlah hari saat penggunaan untuk rekreasi dalam 1 tahun 
$\mathrm{L}=$ Kebutuhan luas areal termasuk tempat parkir (berdasarkan standar Douglas min. 726 $\mathrm{ft}^{2}$ sampai maksimum $2725 \mathrm{ft}^{2}$ )

$\mathrm{TF}=$ Turnover Factor berdasarkan standar Douglas 43,560 $\mathrm{ft}^{2}$ atau 0,001 yaitu konstanta 1,5

Setelah itu, langkah selanjutnya adalah menghitung kebutuhan areal per orang. Berikut adalah rumus tersebut.

Kebutuhan areal per orang :

Keterangan :

$$
\mathrm{KA}(0)=\frac{K A}{D}
$$

$\mathrm{KA}(\mathrm{O}) \quad=$ Kebutuhan areal $\left(\mathrm{m}^{2} /\right.$ orang/hari)

$\mathrm{KA} \quad=$ Kebutuhan areal $\left(\mathrm{m}^{2}\right)$

$\mathrm{D} \quad=$ Rata - rata jumlah kunjungan per hari

Dan langkah terakhir, yaitu menghitung daya dukung kawasan dengan rumus sebagai berikut.

$$
\mathrm{DD}=\frac{L E}{K A(O)}
$$

Keterangan :

$\mathrm{DD} \quad=$ Daya dukung kawasan

$\mathrm{KA}(\mathrm{O}) \quad=$ Kebutuhan areal $\left(\mathrm{m}^{2} /\right.$ orang/hari)

$\mathrm{LE} \quad=$ Luas area untuk rekreasi

Dengan semua dasar rumus di atas, maka dapat dilakukan perhitungan dalam mengetahui daya dukung kawasan. Berikut adalah perhitungan tersebut.

$$
\mathrm{KA}=\frac{D \times L}{C D \times T F \times 43,560 f t^{2}}
$$

$$
\begin{aligned}
& \mathrm{KA}=\frac{8.395 \text { jiwa } \times 726 \mathrm{ft}^{2}}{365 \text { hari } \times 1,5 \times 43,560 \mathrm{ft}^{2}} \quad \mathrm{KA}=\frac{8.395 \text { jiwa } \times 2725 \mathrm{ft}^{2}}{365 \text { hari } \times 1,5 \times 43,560 \mathrm{ft}^{2}} \\
& \mathrm{KA}=\frac{6.094 .770}{23.849 .100}=0,256 \text { acre } \times 0,405 \quad \mathrm{KA}=\frac{22.876 .375}{23.849 .100}=0,959 \text { acre } \times 0,405 \\
& \mathrm{KA}=0,103 \mathrm{Ha} \times 10.000=1030 \mathrm{~m}^{2} \quad \mathrm{KA}=0,388 \mathrm{Ha} \times 10.000=3880 \mathrm{~m}^{2}
\end{aligned}
$$

Kebutuhan areal per orang :

$$
\begin{array}{ll}
\text { KA (0) }=\frac{1.030 \mathrm{~m}^{2}}{23} & \text { KA }(0)=\frac{3880 \mathrm{~m}^{2}}{23} \\
\mathrm{KA}(0)=45 \mathrm{~m}^{2} / \text { orang } / \text { hari } & \text { KA }(0)=168 \mathrm{~m}^{2} / \text { orang } / \text { hari }
\end{array}
$$

Daya dukung kawasan :

$$
\begin{aligned}
\mathrm{DD}=\frac{L E}{K A(O)} & \\
\mathrm{DD}=\frac{21.000 \mathrm{~m}^{2}}{45 \mathrm{~m}^{2} / \text { orang } / \text { hari }} & \mathrm{DD}=\frac{21.000 \mathrm{~m}^{2}}{168 \mathrm{~m}^{2} / \text { orang } / \text { hari }} \\
\mathrm{DD}=466,66 \text { orang }=467 \text { orang } / \text { hari } & \mathrm{DD}=125 \text { orang / hari }
\end{aligned}
$$

Dari hasil perhitungan di atas maka jumlah pengunjung yang dapat ditampung oleh kawasan objek studi adalah sebanyak 125 orang / hari hingga maksimum 467 orang / hari. Hasil tersebut menjadi ketentuan dalam mengetahui batas jumlah pengunjung yang datang, sehingga dapat menghidari kerusakan kawasan objek studi. 


\section{Analisis Best Practices}

Analisis ini berguna untuk mengetahui strategi pengelolaan terkait objek wisata serupa dengan objek penelitian. Berikut ini merupakan beberapa informasi mengenai strategi dan aspek pengelolaan wisata serupa dengan tujuan untuk mengetahui posisi objek studi terhadap objek wisata lainnya. Objek wisata dengan konsep wisata alam yang mirip dengan objek studi adalah Curug Bidadari yang berlokasi di Sentul, Kabupaten Bogor, Jawa Barat dan Curug Ciherang yang berlokasi di Kecamatan Sukamakmur, Kabupaten Bogor, Jawa Barat.

Kawasan Curug Bidadari dengan objek studi memiliki persamaan konsep wisata, yaitu air terjun dengan kolam buatan disekitarnya. Sedangkan untuk Curug Ciherang adalah air terjun yang memiliki wisata alam lainnya di kawasan tersebut seperti rumah pohon, jembatan gantung, dan kolam renang. Terdapat beberapa aspek - aspek tertentu dalam pengelolaan kawasan yang berguna untuk mengetahui kelebihan dan kekurangan perbandingan antara Curug Bidadari serta Curug Ciherang dengan objek studi dengan membandingkan aspek - aspek tersebut. Berikut ini adalah tabel perbandingan kedua objek studi pembanding.

Tabel 3. Objek Studi Pembanding

\begin{tabular}{|c|c|c|}
\hline $\begin{array}{c}\text { Aspek } \\
\text { Pengelolaan }\end{array}$ & Curug Bidadari & Curug Ciherang \\
\hline Manajemen & $\begin{array}{l}\text { - Pembersihan kawasan air terjun } \\
\text { dilakukan setiap hari dan kolam } \\
\text { renang dilakukan satu kali dalam satu } \\
\text { minggu di hari senin. } \\
\text { - Pemeriksaan dan perbaikan sumber } \\
\text { daya, fasilitas, sarana dan prasarana } \\
\text { jika ada kerusakan setiap satu } \\
\text { minggu. } \\
\text { - Pengelolaan lapangan yang terdiri } \\
\text { dari front office, ticketing, } \\
\text { kebersihan, operasional dan servis, } \\
\text { keamanan. }\end{array}$ & $\begin{array}{l}\text { - Pengelolaan lapangan yang terdiri } \\
\text { dari front office, ticketing, } \\
\text { kebersihan, operasional dan servis, } \\
\text { keamanan. } \\
\text { - Pembersihan kawasan air terjun dan } \\
\text { wahana disekitarnya yang dilakukan } \\
\text { satu kali dalam seminggu di hari } \\
\text { kamis. } \\
\text { - Pengawasan terhadap air terjun, } \\
\text { pepohonan, dan ekosistem } \\
\text { disekitarnya dengan tujuan untuk } \\
\text { menjaga kondisi kelestarian alam. } \\
\text { - Pemeliharaan fasilitas dengan cara } \\
\text { memperbaiki sarana dan prasarana } \\
\text { jika ada kerusakan. }\end{array}$ \\
\hline $\begin{array}{c}\text { Sumber Daya } \\
\text { Manusia }\end{array}$ & $\begin{array}{l}\text { - Ketenagakerjaan dikelola oleh pihak } \\
\text { Sentul Paradise Park dengan sumber } \\
\text { daya manusia yang berasal dari } \\
\text { beberapa pihak Sentul Paradise Park } \\
\text { dan masyarakat sekitar. } \\
\text { - Memberi kesempatan usaha untuk } \\
\text { masyarakat sekitar dengan cara } \\
\text { memberi tempat untuk berjualan } \\
\text { makanan, minuman, dll. }\end{array}$ & 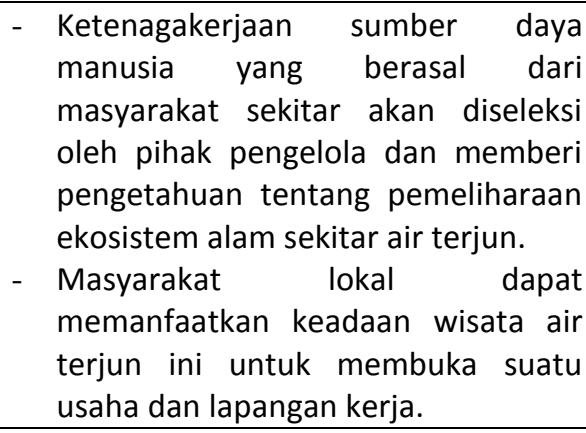 \\
\hline $\begin{array}{c}\text { Sarana dan } \\
\text { Prasarana }\end{array}$ & $\begin{array}{ll} & \text { Musholla } \\
\text { - } & \text { Toilet umum } \\
\text { - } & \text { Tempat parkir } \\
\text { - } & \text { Saung } \\
\text { - } & \text { P3K } \\
\text { - } & \text { Warung makan } \\
\text { - } & \text { Kolam renang } \\
\text { - } & \text { Tempat penitipan barang }\end{array}$ & $\begin{array}{ll} & \text { Musholla } \\
\text { - } & \text { Toilet umum } \\
\text { - } & \text { Tempat parkir } \\
\text { - } & \text { Warung makan } \\
\text { - } & \text { P3K } \\
\text { - } & \text { Kolam renang } \\
\text { - } & \text { Taman bermain } \\
\text { - } & \text { Gazebo }\end{array}$ \\
\hline $\begin{array}{c}\text { Daya Tarik } \\
\text { Wisata dan } \\
\text { Event }\end{array}$ & $\begin{array}{ll}\text { - } & \text { Menikmati keindahan alam } \\
\text { - } & \text { Flying Fox } \\
\text { - } & \text { Naik perahu } \\
\text { - } & \text { Kolam renang } \\
\end{array}$ & $\begin{array}{ll}\text { - } & \text { Menikmati keindahan alam } \\
\text { - } & \text { Kolam renang } \\
\text { - } & \text { Rumah pohon } \\
\text { - } & \text { Jembatan gantung } \\
\end{array}$ \\
\hline
\end{tabular}




\begin{tabular}{|c|c|c|}
\hline & & - Camping ground \\
\hline Promosi & $\begin{array}{l}\text { - Pemasangan spanduk. } \\
\text { - Diskon tiket masuk pada waktu } \\
\text { tertentu. } \\
\text { - Membuat dan menyebarkan brosur. } \\
\text { - Menawarkan paket acara untuk } \\
\text { kantor dan keluarga. }\end{array}$ & $\begin{array}{l}\text { - Membuat papan penunjuk arah } \\
\text { disekitar jalan } \\
\text { - Memasang spanduk } \\
\text { - Promosi melalui sosial media } \\
\text { - Penyebaran secara internal. }\end{array}$ \\
\hline
\end{tabular}

Sumber: Olahan Penulis

Dari kedua objek studi pembanding dengan data - data sistem pengelolaan di atas dapat memberikan kajian yang dapat diterapkan pada sistem pengelolaan objek studi penelitian. Walaupun kedua objek studi pembanding memiliki kelebihan dan kekurangan nya masing masing. Berikut adalah beberapa aspek dari kedua objek studi pembanding dan Standar Nasional Indonesia tentang pengelolaan wisata alam.

a. Keterlibatan Masyarakat

Dengan adanya wisata alam, keterlibatan masyarakat sekitar dapat memberi dampak positif terhadap masyarakat tersebut karena mendapatkan lapangan usaha dan pekerjaan yang akan diseleksi oleh pihak pengelola. Selanjutnya, masyarakat akan diberi pengetahuan tentang pemeliharaan ekosistem alam sehingga masyarakat tersebut dapat berperan dalam pengelolaan menjaga kelestarian wisata alam itu sendiri.

b. Sistem Pengelolaan

Wisata alam harus memiliki sistem pengelolaan yang baik serta dibantu dengan organisasi dan SOP yang jelas. Sehingga dapat membantu pihak pengelola dalam menjaga kualitas wisata alam sesuai dengan standar yang ditentukan.

c. Pemeliharaan Ekosistem Alam

Terdapat pengawasan lebih terhadap wisata dan ekosistem disekitarnya. Hal ini bertujuan untuk menjaga kondisi kelestarian alam serta beberapa kegiatan di wisata alam tersebut dengan memperhatikan kaidah konservasi.

d. Edukasi

Selain pihak pengelola, para masyarakat dan pengunjung juga harus mendapatkan edukasi tentang pentingnya menjaga kawasan wisata alam dengan ekosistem disekitarnya. Hal ini juga harus dibantu dengan penyediaan sarana yang dapat membantu masyarakat dan pengunjung untuk belajar khususnya dalam hal kebersihan kawasan objek studi.

e. Keselamatan Pengunjung

Selain menjaga kelestarian alam, keselamatan pengunjung juga menjadi suatu prioritas yang tidak bisa ditinggalkan. Pihak pengelola harus menyediakan sarana dan prasarana untuk menjaga keselamatan pengunjung dan upaya pertolongan dari suatu kejadian atau kecelakaan. Beberapa contoh nya seperti P3K, papan peringatan yang tidak boleh dilakukan oleh pengunjung, batas kawasan untuk wisata, dll. Selain itu juga harus tersedia sumber daya manusia yang mengetahui atau ahli dalam bidang medis.

\section{Analisis Preferensi Pengunjung}

Untuk mengetahui lebih dalam tentang preferensi pengunjung pada objek studi penelitian, maka akan dikelompokkan beberapa bagian kuisioner yaitu sebagai berikut.

a. Profil dan karakteristik pengunjung

b. Tujuan kunjungan

c. Preferensi pengunjung

Berdasarkan hasil sampel kuisioner yang terkumpul untuk melakukan penelitian ini dapat dikelompokkan menjadi beberapa bagian. Berikut adalah bagian - bagian tersebut.

a. Profil dan karakteristik pengunjung.

b. Kunjungan

c. Preferensi pengunjung. 


\section{Profil dan Karakteristik Pengunjung}

a) Jenis Kelamin

Dalam penyebaran kuisioner pada kawasan Curug Luhur mendapatkan hasil bahwa jenis kelamin pengunjung wisata didominasi oleh laki - laki sebesar $52 \%$ sedangkan untuk perempuan sebesar $48 \%$

b) Usia

Pada bagian usia, pengunjung yang datang di kawasan Curug Luhur didominasi oleh pengunjung dengan usia $17-30$ tahun sebesar $71 \%$, sisanya terdapat pengunjung yang bersuia 31 - 45 tahun sebesar 20\%, dibawah 17 tahun sebesar 6\%, $46-55$ tahun sebesar $3 \%$, dan lebih dari 55 tahun sebesar $0 \%$.

c) Tempat Tinggal

Untuk tempat tinggal pengunjung kawasan Curug Luhur didominasi oleh masyarakat yang berasal dari Jakarta dengan persenatase sebesar 34\%. Persentase terbesar kedua ditempati oleh masyarakat Kabupaten Bogor sebesar $21 \%$. Sisanya terdapat masyarakat daerah Kota Bogor sebesar 12\%, masyarakat daerah Bekasi sebesar 10\%, masyarakat daerah Depok sebanyak 9\%, masyarakat daerah Tanggerang sebanyak $8 \%$, dan yang terkecil adalah masyarakat asal daerah lainnya seperti Ambon, Sulawesi, dan Sumatra sebanyak 6\%.

d) Jenis Pekerjaan

Dalam hal jenis pekerjaan, para pengunjung yang datang ke akwasan Curug Luhur didominasi oleh pelajar / mahasiswa sebanyak $55 \%$. Selain itu juga terdapat pegawai swasta sebesar $26 \%$ dan diikuti oleh pegawai negeri sebesar $8 \%$, pekerjaan lainnya seperti guru, atlet, dan driver sebesar $7 \%$, dan yang terakhir terdapat wiraswasta sebesar $4 \%$.

e) Pendapatan Perbulan

Untuk pendapatan perbulan pengunjung kawasan Curug Luhur terdapat jumlah yang beragam. Jumlah pendapatan perbulan pengunung yang mendominasi adalah dibawah Rp 3.000 .000 dengan persentase sebesar $47 \%$. Selanjutnya adalah pendapatan sebesar Rp 3.000 .000 - Rp 6.000.000 sebesar 31\% diikuti oleh pendapatan sebesar Rp 6.000.000 9.000.000 sebanyak 17\%, pendapatan sebesar Rp 9.000.000- Rp 12.000 .000 sebesar 3\%, dan terakhir adalah pendapartan sebesar lebih dari Rp 12.000 .000 sebanyak $2 \%$.

\section{Kunjungan}

Tujuan Kunjungan

Menurut hasil kuisioner yang sudah disebar, dalam tujuan kunjungan para pengunjung di kawasan Curug Luhur terdapat 55\% pengunjung bertujuan untuk berwisata. Angka tersebut juga menjadi yang terbesar dalam tujuan kunjungan para pengunjung. Sisanya terdapat $20 \%$ dengan tujuan untuk kumpul keluarga / teman, tujuan untuk mengenal tempat wisata sebesar $17 \%$, tujuan untuk bersinggah dari perjalanan / touring sebesar $5 \%$, dan yang terakhir adalah lainnya sebesar $2 \%$ yaitu pengunjung untuk mengikuti suatu acara dan liburan dari kantor.

\section{Daya Tarik}

Berdasarkan hal daya tarik yang mendominasi kawasan Curug Luhur adalah air terjun dan alam yang indah dengan persentase sebesar $67 \%$, pada posisi kedua setelah air terjun dan alam terdapat 2 daya tarik dengan persentase yang sama yaitu kolam renang dan ketiga dari semua daya tarik sebesar $13 \%$. Dan daya tarik terakhir adalah dekat dengan tempat tinggal dengan persentase $7 \%$.

\section{Rekan Wisata}

Pengunjung memiliki rekan wisata dalam mengunjungi kawasan Curug Luhur. Rekan wisata dengan persentase terbesar adalah bersama teman sebesar $43 \%$, kedua bersama keluarga / saudara dengan angka persentase $41 \%$, sedangkan untuk komunitas / rombongan sebesar $9 \%$, dengan lainnya sebesar $5 \%$, dan yang terakhir sendiri dengan angka $2 \%$. 


\section{Objek Studi yang Dikunjungi}

Menurut objek studi yang dikunjungi pada kawasan Curug luhur terdapat 2 objek studi yaitu air terjun dan kolam renang. Persentase terbesar terdapat pada objek Air terjun dengan angka sebesar 58\%, kedua adalah kedua objek yang ada di objek studi tersebut dengan angka persentase $30 \%$, dan yang terakhir adalah kolam renang dengan angka persentase $12 \%$.

\section{Awal Mengetahui Objek Wisata}

Untuk mengetahui asal para pengunjung mengetahui kawasan Curug Luhur juga terdapat beberapa media. Media yang mendominasi terdapat pada media sosial dan internet dengan persentase sebesar $52 \%$, dan diikuti oleh rekomendasi orang terdekat sebesar $48 \%$. Sedangkan untuk media cetak mendapat angka $0 \%$ karena pihak pengelola tidak mencantumkan atau mempromosikan objek wisata pada majalah atau koran.

Waktu Kunjungan (frekuensi, hari, dan lama kunjungan)

Dalam hal frekuensi pada waktu kujungan didominasi oleh pengunjung yang datang sebanyak satu kali dengan persentase angka 56\%, setelah itu diikuti oleh pengunjung yang datang sebanyak dua kali dengan persentase sebesar $33 \%$, pengunjung yang datang sebanyak tiga kali sebesar $8 \%$, dan yang terakhir pengunjung yang datang lebih dari tiga kali sebesar $3 \%$. Sedangkan untuk lama waktu kunjungan dalam satu kali kunjungan didominasi oleh pengunjung yang menghabiskan waktu selama $1-2$ jam dengan persentase sebesar $46 \%$. Selanjutnya terdapat pengunjung yang menghabiskan waktu selama $2-4$ jam sebesar $43 \%$. Sisanya diikuti oleh pengunjung yang menghabiskan waktu selama $4-6$ jam sebanyak $6 \%$, kurang dari 1 jam sebesar 4\%, dan yang terakhir adalah waktu kunjungan selama lebih dari 6 jam. Setelah itu terdapat waktu kunjungan yang didominasi oleh pengunjung yang datang pada akhir minggu sebesar $45 \%$. Kedua adalah waktu kunjungan saat ada acara tertentu dengan persentase sebesar $22 \%$ dan hari libur nasional sebesar $22 \%$. Terakhir terdapat pengunjung yang datang saat weekday dengan persentase sebesar $16 \%$. L selanjutnya adalah mengetahui pola kunjungan studi paling banyak menggunakan analisi crosstab antara frekuensi kunjungan dengan lama waktu kunjungan dan frekuensi kunjungan dengan waktu kunjungan. Berikut adalah anailis tersebut.

Tabel 4. Crosstab Frekuensi Kunjungan Dengan Lama Waktu Kunjungan

\begin{tabular}{|c|c|c|c|c|c|c|c|}
\hline \multicolumn{7}{|c|}{ Lama waktu kunjungan } & \multirow[t]{2}{*}{ Total } \\
\hline & & $<1$ Jam & $1-2$ Jam & 2-4 Jam & $4-6$ jam & > 6jam & \\
\hline \multirow{4}{*}{$\begin{array}{l}\text { Frekuensi } \\
\text { Kunjungan }\end{array}$} & 1 kali & 2 & $\underline{24}$ & $\underline{24}$ & 5 & 1 & 56 \\
\hline & 2 kali & 2 & 16 & 15 & 0 & 0 & 33 \\
\hline & 3 kali & 0 & 5 & 3 & 0 & 0 & 8 \\
\hline & > 3 kali & 0 & 1 & 1 & 1 & 0 & 3 \\
\hline \multicolumn{2}{|c|}{ Total } & 4 & 46 & 43 & 6 & 1 & 100 \\
\hline
\end{tabular}

Sumber : Olahan Penulis, 2019

Tabel 5. Crosstab Frekuensi Kunjungan Dengan Waktu Kunjungan

\begin{tabular}{|c|c|c|c|c|c|c|}
\hline \multicolumn{6}{|c|}{ Waktu kunjungan } & \multirow[t]{2}{*}{ Total } \\
\hline & & Weekday & Weekend & $\begin{array}{l}\text { Harilibur } \\
\text { nasional }\end{array}$ & $\begin{array}{c}\text { Saat ada acara } \\
\text { tertentu }\end{array}$ & \\
\hline \multirow{4}{*}{$\begin{array}{l}\text { Frekuensi } \\
\text { Kunjungan }\end{array}$} & 1 kali & 10 & $\underline{33}$ & 5 & 8 & 56 \\
\hline & 2 kali & 3 & 10 & 10 & 10 & 33 \\
\hline & 3 kali & 3 & 2 & 1 & 2 & 8 \\
\hline & $>3$ kali & 0 & 0 & 1 & 2 & 3 \\
\hline \multicolumn{2}{|c|}{ Total } & 16 & 45 & 17 & 22 & 100 \\
\hline
\end{tabular}

Sumber : Olahan Penulis, 2019 


\section{Moda Transportasi yang Digunakan}

Pada bagian moda transportasi terbanyak yang digunakan oleh pengunjung ke kawasan Curug Luhur adalah kendaraan pribadi roda 2 dengan persentase sebesar $65 \%$ dan untuk kendaraan pribadi roda 4 sebesar $35 \%$. Sedangkan untuk kendaraan umum sebesar $0 \%$ karena tidak tersedianya kendaraan umum yang melewati kawasan objek studi.

\section{Pengeluaran Biaya Saat Berkunjung}

Para pengunjung yang datang ke kawasan Curug Luhur juga mengeluarkan biaya untuk memenuhi kebutuhan. Pengeluaran dengan persentase terbesar adalah Rp $100.000-\mathrm{Rp}$ 200.000 dengan angka 58\%. Terbesar kedua adalah kurang dari Rp. 100.000 dengan persentase 20\%. Sisanya terdapat Rp 200.000 - Rp 400.000 dengan persentase 18\%. Terakhir adalah pengunjung dengan pengeluaran biaya lebih dari Ro 400.000 sebesar $4 \%$.

\section{Preferensi Pengunjung}

Beberapa hal yang akan dibahas dalam bagian preferensi pengunjung adalah mengetahui tingkat kepuasan dan kepentingan dari beberapa kategori dan aspek pengelolaan seperti aksesibilitas, fasilitas, dan pekerja / staff dari kawasan objek studi. Metode yang digunakan untuk menganalisis hasil dari preferensi pengunjung tersebut adalah IPA (Importance Performance Analysis). Berikut adalah hasil dari nilai kepuasan dan kepentingan preferensi pengunjung kawasan Curug Luhur.

Tabel 6. Nilai Kepuasan dan Kepentingan

\begin{tabular}{|c|c|c|c|c|}
\hline No. & Kategori & Faktor Penilaian & Nilai Kepuasan & $\begin{array}{c}\text { Nilai } \\
\text { Kepentingan }\end{array}$ \\
\hline 1. & \multirow{3}{*}{ Aksesibilitas } & Kondisi fisik jalan menuju lokasi & 2,75 & 3,91 \\
\hline 2. & & $\begin{array}{l}\text { Ketersediaan papan petunjuk arah } \\
\text { menuju lokasi }\end{array}$ & 2,28 & 3,92 \\
\hline 3. & & Ketersediaan transportasi umum & 2,07 & 3,78 \\
\hline 4. & \multirow{10}{*}{ Fasilitas } & $\begin{array}{l}\text { Kondisi dan ketersediaan saung / } \\
\text { gazebo. }\end{array}$ & 3,19 & 3,70 \\
\hline 5. & & $\begin{array}{l}\text { Kondisi dan ketersediaan kolam } \\
\text { renang. }\end{array}$ & 3,01 & 3,57 \\
\hline 6. & & $\begin{array}{l}\text { Kondisi dan ketersediaan warung } \\
\text { makan. }\end{array}$ & 2,82 & 3,43 \\
\hline 7. & & $\begin{array}{l}\text { Kondisi dan ketersediaan taman } \\
\text { bermain }\end{array}$ & 2,82 & 3,43 \\
\hline 8. & & $\begin{array}{l}\text { Kondisi dan ketersediaan sarana } \\
\text { ibadah. }\end{array}$ & 2,57 & 3,81 \\
\hline 9. & & $\begin{array}{l}\text { Kondisi dan ketersediaan sarana } \\
\text { parkir. }\end{array}$ & 2,98 & 3,92 \\
\hline 10. & & $\begin{array}{l}\text { Kondisi dan ketersediaan tempat } \\
\text { sampah. }\end{array}$ & 2,15 & 4,06 \\
\hline 11. & & Kondisi dan ketersediaan toilet.. & 1,59 & 4,00 \\
\hline 12. & & $\begin{array}{l}\text { Kondisi dan ketersediaan air } \\
\text { bersih.. }\end{array}$ & 2,41 & 4,01 \\
\hline 13. & & $\begin{array}{lll}\text { Kondisi dan } & \text { ketersediaan } \\
\text { kelistrikan. } & & \\
\end{array}$ & 2,45 & 3,95 \\
\hline 14. & \multirow{3}{*}{ Pekerja / Staff } & $\begin{array}{l}\text { Kondisi dan ketersediaan petugas } \\
\text { kebersihan }\end{array}$ & 2,28 & 3,76 \\
\hline 15. & & $\begin{array}{l}\text { Kondisi dan ketersediaan petugas } \\
\text { tiket dan pusat informasi. }\end{array}$ & 2,46 & 3,60 \\
\hline 16. & & $\begin{array}{l}\text { Kondisi dan ketersediaan petugas } \\
\text { parkir. }\end{array}$ & 2,40 & 3,40 \\
\hline
\end{tabular}

Sumber : Olahan Penulis, 2019 
Setelah mengetahui nilai kepuasan dan kepentingan dari setiap kategori dan aspek pengelolaan kawasan objek studi, selanjutnya adalah mengola data tersebut menggunakan diagram scatter yang terbagi menjadi 4 kuadran skala prioritas. Skala prioritas tersebut adalah prioritas utama, pertahankan prestasi, prioritas rendah dan berlebihan. Berikut adalah keterangan dari setiap skala tersebut.

Kuadran A : Prioritas utama (tingkat kepentingan tinggi dengan tingkat kepuasan rendah) Kuadran B : Pertahankan prestasi (tingkat kepentingan tinggi dengan tingkat kepuasan baik) Kuadran C : Prioritas rendah (tingkat kepentingan rendah dengan kondisi tidak baik) Kuadrad D : Berlebihan (tingkat kepentingan rendah dengan kondisi baik)

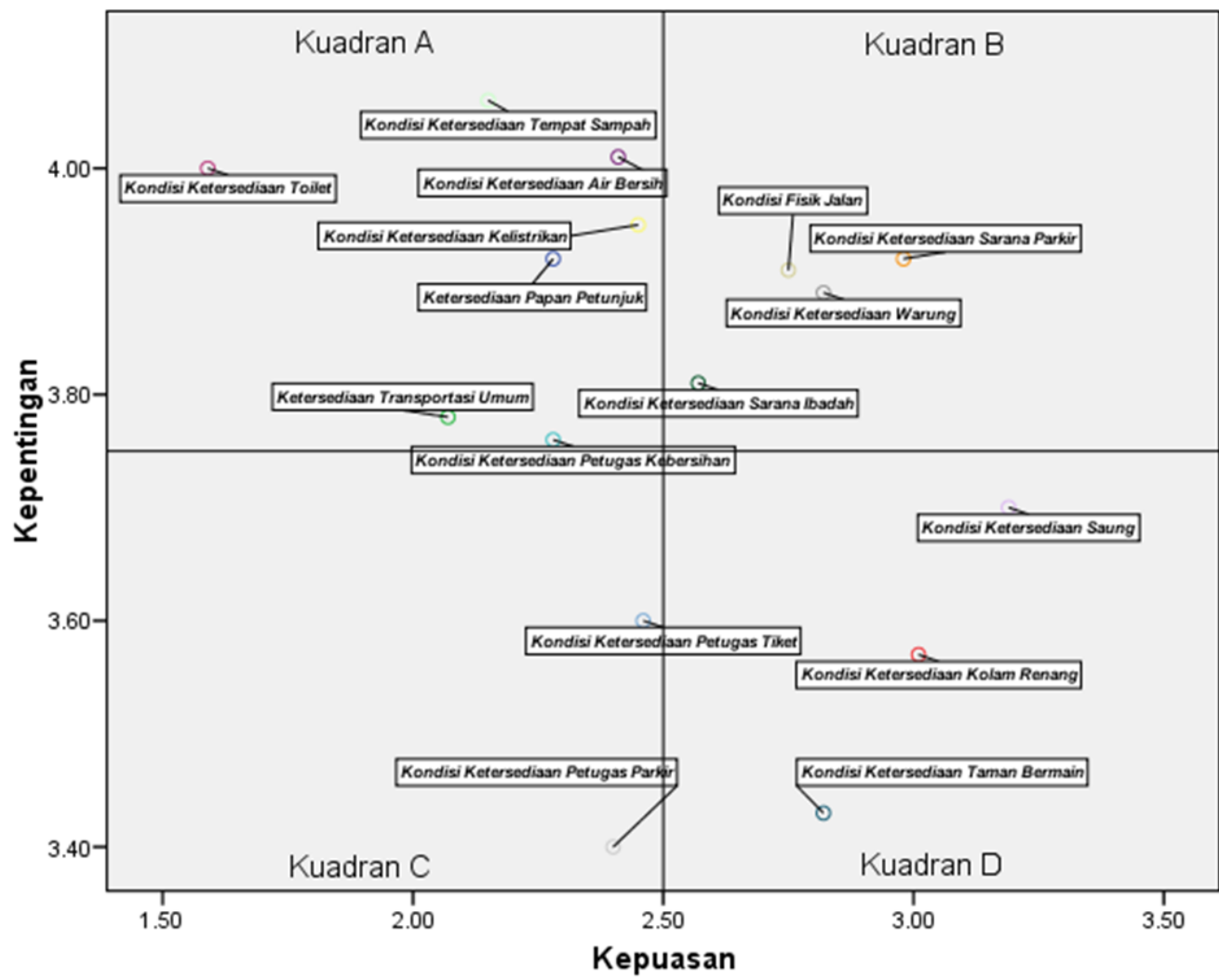

Gambar 11. Diagram Cartesius Preferensi Pengunjung Sumber : Olahan Penulis, 2019

Berikut adalah tabel penjelasan dari hasil diagram cartesius mengenai preferensi pengunjung mengenai konsidi tingkat kepuasan maupun tingkat kepentingan pengelolaan kawasan Curug Luhur.

Tabel 7. Nilai Kepuasan dan Kepentingan Berdasarkan Kuadran

\begin{tabular}{|c|c|c|c|c|c|}
\hline \multirow{2}{*}{ No. } & \multirow{2}{*}{ Kategori } & \multicolumn{4}{|c|}{ Kalsifikasi } \\
\hline & & Kuadran A & Kuadran B & Kuadran C & Kuadran D \\
\hline \multirow[b]{2}{*}{1.} & \multirow[b]{2}{*}{ Aksesibilitas } & Papan petunjuk & \multirow[b]{2}{*}{ Kondisi jalan } & & \\
\hline & & $\begin{array}{c}\text { Transportasi } \\
\text { umum }\end{array}$ & & & \\
\hline \multirow{4}{*}{2.} & \multirow{4}{*}{ Fasilitas } & Tampat sampah & Sarana parkir & & Saung / Gazebo \\
\hline & & Air bersih & Warung & & Kolam renang \\
\hline & & Toilet & \multirow{2}{*}{ Sarana ibadah } & & \multirow{2}{*}{ Taman bermain } \\
\hline & & Kelistrikan & & & \\
\hline \multirow{2}{*}{3.} & \multirow{2}{*}{ Pekerja / Staff } & \multirow{2}{*}{$\begin{array}{l}\text { Petugas } \\
\text { kebersihan }\end{array}$} & & Petugas tiket & \\
\hline & & & & Petugas parkir & \\
\hline
\end{tabular}

Sumber : Olahan Penulis, 2019 
Tabel di atas adalah hasil klasifikasi prioritas menurut preferensi pengunjung yang menjadi responden penelitian. Selain itu, berikut adalah hasil penjabaran dari klasifikasi prioritas tersebut berdasarkan pengamatan dan hasil wawancara.

Tabel 8. Penjelasan Nilai Kepuasan dan Kepentingan Berdasarkan Kuadran

\begin{tabular}{|c|c|}
\hline Kuadran & Penjelasan \\
\hline $\begin{array}{c}\text { Kuadran A (Prioritas } \\
\text { utama) }\end{array}$ & $\begin{array}{l}\text { - Papan petunjuk adalah hal yang penting untuk menunjukan suatu arah } \\
\text { sehingga para pengunjung lebih mudah mengetahui lokasi objek studi. } \\
\text { Sedangkan Curug Luhur tidak memiliki papan petunjuk sama sekali } \\
\text { sehingga para pengunjung menjadi kesulitan untuk mencari kawasan } \\
\text { objek studi tersebut. } \\
\text { - Transportasi umum bisa menjadi salah satu prioritas utama karena } \\
\text { dapat mempermudah para wisatawan untuk mengunjungi kawasan } \\
\text { objek studi tanpa harus menggunakan kendaraan pribadi. Sangat } \\
\text { disayangkan bahwa tidak ada transportasi umum yang mencapai } \\
\text { kawasan objek studi. } \\
\text { - Beberapa sampah juga masih tersebar di kawasan objek studi karena } \\
\text { kurangnya tempat sampah dan kondisi tempat sampah yang tidak layak } \\
\text { pakai. } \\
\text { Air bersih di kawasan objek studi juga menjadi prioritas utama karena } \\
\text { air bersih tersebut berguna bagi para pengujung untuk mandi, buang air, } \\
\text { dll. Sedangkan air bersih di kawasan ini belum tersebar secara merata } \\
\text { sehingga masih ada beberapa toilet yang tidak mendapatkan air bersih. } \\
\text { Kelistrikan di kawasan objek studi juga masih tidak merata karena masih } \\
\text { ada beberapa toilet yang tidak mendapatkan cahaya sama sekali. Hal ini } \\
\text { disebabkan lampu yang ada di toilet tersebut tidak dapat dipakai. } \\
\text { Petugas kebersihan juga menjadi salah satu faktor penting dalam } \\
\text { menjaga kebersihakn kawasan objek studi, kurang nya tempat sampah } \\
\text { dan banyak nya warung yang tersebar membuat volume sampah } \\
\text { menjadi sulit untuk ditampung. Kualitas petugas kebersihan bisa } \\
\text { dikatakan kurang baik karena masih ada beberapa sampah yang } \\
\text { tersebar di kawasan objek studi sehingga pihak pengelola harus lebih } \\
\text { memperhatikan kualitas kepegawaian. }\end{array}$ \\
\hline $\begin{array}{c}\text { Kuadran B } \\
\text { (Pertahankan) }\end{array}$ & $\begin{array}{l}\text { - Dalam hal aksesibilitas, meskipun masih ada beberapa jalan yang } \\
\text { berlubang kecil, kondisi fisik jalan secara keseluruhan sudah cukup baik } \\
\text { sehinnga para pengunjung merasa nyaman saat berkendara menuju ke } \\
\text { kawasan objek studi. } \\
\text { - Sarana parkir juga sudah cukup baik karena memiliki daya tampung yang } \\
\text { cukup baik dengan lahan yang tidak merusak ekosistem sekitar kawasan } \\
\text { air terjun. } \\
\text { - Kondisi dan keberadaan warung disekitar kawasan objek studi harus } \\
\text { dipertahankan karena para pengunjung menjadi lebih mudah untuk } \\
\text { membeli kebutuhan seperti makanan, minuman, baju renang, } \\
\text { pelampung, dll. tanpa harus keluar kawasan Curug Luhur. } \\
\text { - Sarana ibadah di kawasan objek studi juga memiliki kondisi yang cukup } \\
\text { baik dan layak pakai sehingga harus dipertahankan. Sarana ini memiliki } \\
\text { daya tampung sekitar } 5 \text { - } 6 \text { orang dan sudah dilengkapi dengan air bersih } \\
\text { dan alat ibadah. }\end{array}$ \\
\hline $\begin{array}{c}\text { Kuadran C (Prioritas } \\
\text { rendah) }\end{array}$ & $\begin{array}{l}\text { - Dari segi pekerja / staff, petugas tiket memiliki kualitas yang rendah } \\
\text { karena petugas tersebut tidak memberikan informasi tentang kawasan } \\
\text { objek studi dengan jelas, dan hanya sekedar menjual tiket saja. } \\
\text { Sedikitnya informasi yang diberikan untuk pengunjung, smeakin besar } \\
\text { potensi terjadinya kecelakaan atau musibah yang dapat melukai para } \\
\text { pengunjung. Selain itu juga terdapat petugas parkir yang hanya } \\
\text { memberikan tiket parkir tanpa memberi tahu arah tempat parkir }\end{array}$ \\
\hline
\end{tabular}


tersebut. Sehingga petugas parkir menjadi tidak terlalu penting karena tidak membantu para pengunjung.

- Saung / gazebo terdapat di kuadran D dikarenakan meskipun kondisi fasilitaas sudah baik dan bisa menjadi tempat istirahat atau menaruh barang untuk sementara, para pengunjung lebih memilih untuk beristirahat di warung - warung karena lebih mudah untuk membeli kebutuhan tertentu dan untuk menaruh barang juga sudah disediakan tempat penitipan barang dengan keamanan yang lebih baik.

Kuadran D

- Banyaknya kolam renang di kawasan ini termasuk berlebihan karena

(Berlebihian) beberapa pengunjung hanya ingin menikmati indahnya air terjun dan alam disekitarnya sehingga kolam renang memiliki tingkat kepentingan yang rendah.

- Taman bermain juga memiliki tingkat kepentingan yang rendah dan sepi pemakai karena anak - anak disekitar kawasan sudah merasa terpenuhi dengan adanya air terjun dan kolam renang dengan seluncuran dan tempat bermain di sekitar kolam tersebut.

Sumber : Olahan Penulis, 2019

\section{Analisis Strategi Pengelolaan}

Salah satu masalah dari kawasan Curug Luhur adalah tidak memiliki sistem organisasi, maka penulis merekomendasikan sebuah sistem organisasi yang dapat dipakai untuk pihak pengelola kawasan Curug Luhur berdasarkan hasil analisis tersebut. Berikut adalah struktur organisasi rekomendasi penulis.

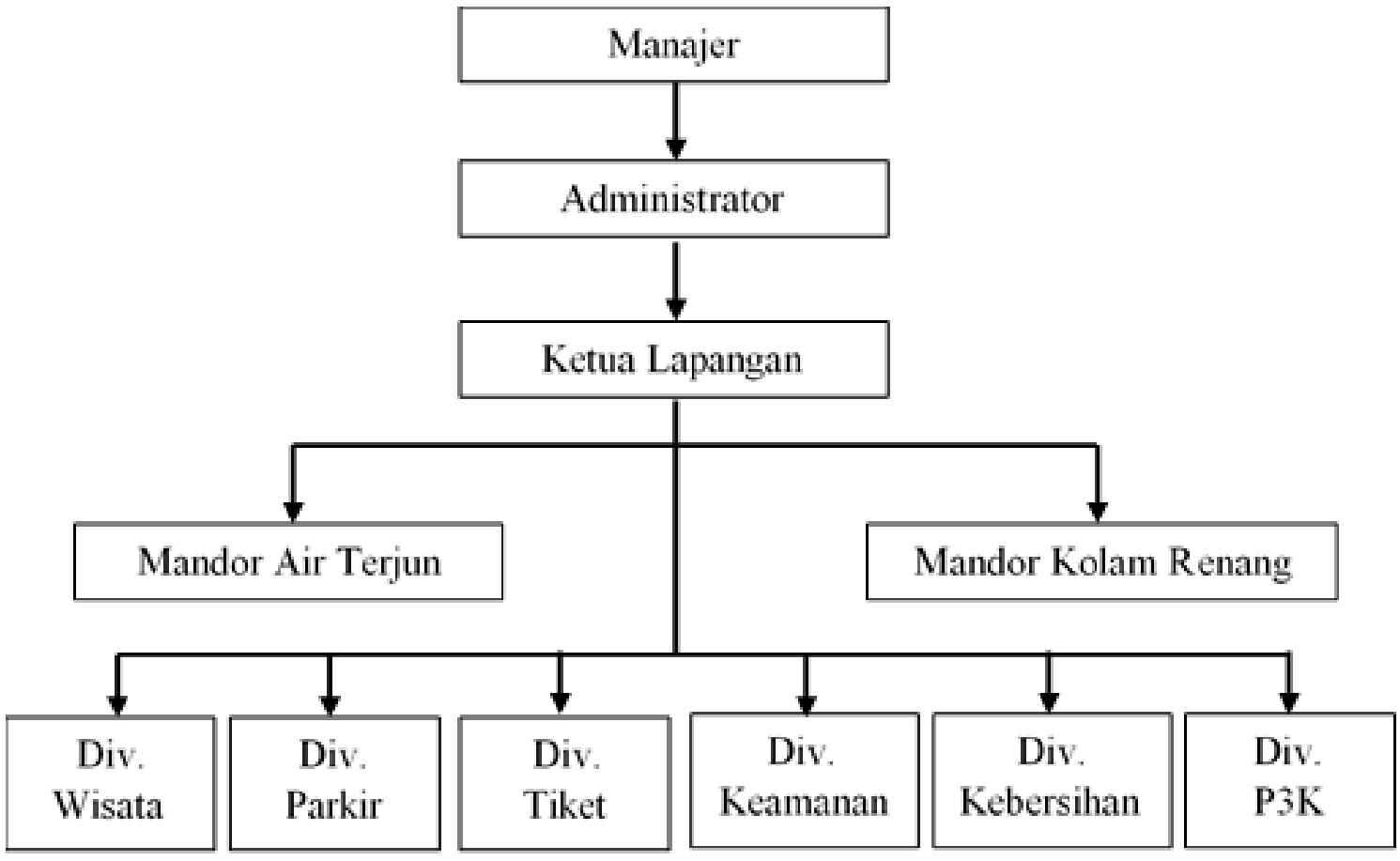

Gambar 12. Bagan Organisasi

Sumber: Olahan Penulis, 2019

Langkah selanjutnya untuk mengetahui strategi pengelolaan yang dapat diterapkan terhadap Curug Luhur dalam bentuk analisis SWOT. Berikut adalah hasil analisis tersebut. 
Tabel 9. Strategi SWOT

\begin{tabular}{|c|c|c|}
\hline Strategi Pengelolaan & Strengths & Weaknesses \\
\hline & $\begin{array}{l}\text { - Lokasi dengan akses yang } \\
\text { dapat dilewati dari berbagai } \\
\text { arah dan daerah. } \\
\text { - Menurut analisis daya } \\
\text { dukung kawasan, kapasitas } \\
\text { pengunjung masih tidak } \\
\text { melebihi saya tampung } \\
\text { kawasan objek studi. } \\
\text { - Keunikan yang dimiliki } \\
\text { kawasan Curug Luhur, yaitu } \\
\text { menggabungkan antara } \\
\text { wisata alam dengan buatan. }\end{array}$ & $\begin{array}{l}\text { - Tidak memliki papan petunjuk } \\
\text { karena pihak pengelola tidak } \\
\text { melakukan penyebaran papan } \\
\text { petunjuk. } \\
\text { - Tidak ada transportasi umum } \\
\text { yang melewati kawasan objek } \\
\text { studi. } \\
\text { - Kurangnya tempat sampah dan } \\
\text { kondisi tempat sampah yang } \\
\text { tidak layak pakai. } \\
\text { - Air bersih dan kelistarikan yang } \\
\text { tidak tersebar secara merata. } \\
\text { - Kurangnya SDM untuk bagian } \\
\text { petugan kebersihan. }\end{array}$ \\
\hline Opportunities & S-O & $\mathbf{W}-\mathbf{0}$ \\
\hline $\begin{array}{l}\text { - Terdapat beberapa kajian } \\
\text { yang dapat diterapkan dari } \\
\text { beberapa aspek, seperti } \\
\text { sistem organisasi } \\
\text { pengelolaan, keterlibatan } \\
\text { dan partisipasi masyarakat, } \\
\text { ekonomi, edukasi, dan } \\
\text { pemeliharaan ekosistem } \\
\text { alam. }\end{array}$ & $\begin{array}{lr}\text { - Dapat meningkatkan angka } \\
\text { pengunjung } & \text { dan } \\
\text { mengevaluasi } & \text { sistem } \\
\text { pengelolaan kawasan objek } \\
\text { studi dengan rara } \\
\text { mempelajari } & \text { sistem } \\
\text { pengelolaan dari } & \text { objek } \\
\text { wisata sejenis. } & \end{array}$ & $\begin{array}{l}\text { - Memperbaiki kualitas fasilitas } \\
\text { dari setiap aspek seperti papan } \\
\text { petunjuk, tempat sampah, air } \\
\text { bersih, dan menambah SDM } \\
\text { dengan cara menerapkan hasil } \\
\text { best practices berupa sistem } \\
\text { organisasi pengelolaan dari } \\
\text { objek studi sejenis. }\end{array}$ \\
\hline Threats & $S-T$ & $\mathbf{W}-\mathbf{T}$ \\
\hline $\begin{array}{l}\text { - Terdapat wisata alam } \\
\text { sejenis di sekitar kawasan } \\
\text { objek studi dengan kondisi } \\
\text { yang lebih baik dengan } \\
\text { harga yang lebih murah. }\end{array}$ & $\begin{array}{l}\text { - Menjual keunikan wisata } \\
\text { yang dimiliki kawasan objek } \\
\text { studi dan membatasi angka } \\
\text { pengunjung yang datang } \\
\text { sehingga kelestarian alam } \\
\text { dan lingkungan kawasan } \\
\text { objek studi tetap terjaga. }\end{array}$ & $\begin{array}{l}\text { - Meningkatkan kualitas } \\
\text { pengelolaan dalam aspek - } \\
\text { aspek tertentu sehingga dapat } \\
\text { memberikan kepuasan untuk } \\
\text { para pengunjung dan tidak } \\
\text { kalah saing dengan pesaing } \\
\text { wisata alam sejenis disekitar } \\
\text { kawasan objek studi. }\end{array}$ \\
\hline
\end{tabular}

Sumber : Olahan Penulis, 2019

Berikut adalah usulan strategi pengelolaan untuk kawasan objek studi berdasarkan hasil tabel analis SWOT.

a. Melakukan penyebaran papan petunjuk disekitar kawasan objek studi sehingga para pengunjung tidak kesulitan untuk mencari lokasi objek studi.

b. Mengusulkan kerja sama dengan penginapan / hotel terdekat untuk melakukan paket tour sehingga para pengunjung mendapat fasilitas untuk mencapai lokasi objek studi tanpa kendaraan pribadi mengingat bahwa rute kendaraan umum hanya mencapai lokasi penginapan / hotel tersebut dan tidak melewati kawasan objek studi.

c. Menambah dan memperbaiki beberapa fasilitas yang memiliki kondisi dan kualitas buruk.

d. Mempelajari dan menerapkan hasil analisi best practices berupa sistem organisasi pengelolaan dari objek studi sejenis.

e. Membuat rencana untuk melakukan pembatasan pengunjung pada objek studi agar menghidari kerusakan alam dan memberi edukasi untuk para pengunjung agar kelestarian alam dan lingkungan kawasan objek studi tetap terjaga. 


\section{KESIMPULAN DAN SARAN}

Setelah melakukan analisis, kita dapat mengetahui potensi dan masalah dari kawasan Curug Luhur. Berikut adalah kesimpulan dan saran untuk rekomendasi pengelolaan terkait aspek pengelolaan dan pariwisata berkelanjutan.

\section{a. Manajemen}

Melakukan pengawasan terhadap objek studi dengan cara merawat dan memelihara kelestarian lingkungan sekitar kawasan objek studi dan salah satu cara nya adalah melakukan pembatasan pengunjung. Selain itu juga memberi program atau SOP yang jelas sehingga para pekerja dari setiap divisi masing - masing dapat mudah dalam mengambil tindakan saat melakukan pekerjaan mereka.

\section{b. Sarana dan Prasarana}

Merawat sarana dan prasarana umum yang memiliki kondisi baik dan meningkatkan sarana dan prasarana umum yang memiliki kondisi buruk dengan cara menambah tempat sampah, daya listrik, air bersih, meningkatkan kebersihan, dan kualitas toilet umum.

c. Sumber daya manusia

Salah satu masalah di kawasan objek studi adalah kurang nya sumber daya manusia sehingga sistem pengelolaan menjadi tidak jalan sesuai rencana. Salah satu solusi untuk menghadapi masalah ini adalah dengan menambah sumber daya manusia yang terdiri dari masyarakat sekitar objek studi. Penambahan sumber daya manusia juga harus melewati tahap proses penerimaan dan pelatihan. Untuk pekerja yang sudah bekerja di kawasan objek studi juga diberi pengarahan dalam bekerja sesuai SOP yang diterapkan.

\section{d. Daya Tarik}

Dalam hal ini, beberapa hal yang harus dilakukan untuk menambah daya tarik wisatawan adalah mengadakan hiburan atau acara tertentu yang dapat dikelola dengan baik tanpa merusak kelestarian alam sekitar kawasan objek studi.

\section{e. Promosi}

Sejauh ini, promosi yang sudah dilakukan hanya melalui rekomendasi orang terdekat, dan media sosial dengan cara mengambil foto, mengunggah foto tersebut, dan melakukan review tentang kawasan objek studi. Sedangkan promosi melalui media cetak tidak pernah dilakukan. Promosi melalui media cetak juga perlu dilakukan sehingga para pembaca dapat mengetahui keberadaan kawasan objek studi dan dapat menambah angka pengunjung.

Selain itu juga terdapat rekomendasi pengelolaan berdasarkan aspek pariwisata berkelanjutan (sustainable tourism). Berikut adalah rekomendasi tersebut.

\section{a. Konservasi}

Kelestarian alam adalah hal yang paling penting dalam pariwisata alam. Sehingga pihak pengelola Curug Luhur harus mengadakan program pengecekan pada kawasan air terjun dan sekitarnya dengan tujuan untuk mengetahui kondisi kelestarian alam sekitar kawasan objek studi. Untuk mempermudah proses program tersebut, para pekerja lapangan juga harus mengawasi kawasan objek studi dari waktu buka sampai waktu tutup.

b. Partisipasi Masyarakat

Selain pihak pengelola, masyarakat sekitar juga memiliki peran yang penting dalam menjaga kelestarian alam di kawasan Curug Luhur, yaitu dengan cara menjadi pegawai atau pekerja dalam pengelolaan kawasan objek studi. Pihak pengelola juga harus memberi edukasi dan arahan untuk masyarakat sekitar yang tidak bekerja dalam pengelolaan kawasan objek studi dengan harapan bisa berparsitipasi dalam menjaga kelestarian alam.

c. Ekonomi

Ada nya kawasan wisata alam seperti Curug Luhur dapat membuka lapangan pekerjaan dan lahan usaha bagi para masyarakat yang tinggal disekitar kawasan tersebut dengan cara bergabung dalam pengelolaan kawasan objek studi dan menjual berbagai makanan, 
minuman, alat renang, dll. untuk para pengunjung. Sehingga hal - hal tersebut diharapkan dapat meingkatkan perekonomian untuk masyarakat sekitar.

\section{d. Infrastruktur}

Infrastruktur kepariwisataan harus dirancang dan kegiatan kepariwisataan harus diprogramkan sedemikian rupa untuk melindungi warisan alam dengan cara memanfaatkan teknologi yang layak/pantas untuk diterapkan di wilayah lingkungan tersebut.

\section{REFERENSI}

Affifiddin. (2010). Pengantar administrasi Pembangunan. Bandung: Alvabeta.

Conyers, D. (1994). Perencanaa Sosial di Dunia Ketiga: Suatu Pengantar. Yogyakarta: Gadjah Mada University Press.

Gamal, S. (2002). Dasar-Dasar Pariwisata. Yogyakarta: Penerbit Andi.

Fandeli, C. dan Mukhlison. (2002). Perencanaan Kepariwisataan Alam. Fakultas Kehutanan UGM. Yogyakarta.

Kepemerintahan Indonesia (2007) Undang-Undang Nomor 26 tentang Penataan Ruang dan Peraturan Menteri PU No.05/PRT/M/2008

Kepemerintahan Indonesia (2009). Undang - Undang no.10 tahun 2009 tentang kepariwisataan.

Kepemerintahan Indonesia (1995). Departemen Pendidikan dan Kebudayaan tentang pengelolaan 1-2.

Muller. H. (1992). Die erste sachische Forstordnung von.1560, Allgemeine Forst-und Jagdzeitung, 163(6), 106-107.

Resosoedarmo, S. (1986). Ekologi. Jakarta: Fakultas Pasca IKIP.

Reksopoetranto, S. (1992). Manajemen Proyek Pembangunan. Jakarta: Lembaga Fakultas Ekonomi Universitas Indonesia.

Wahab, S. (1975). Tourism Management. London: Tourism International Press. 
